e-ISSN. 2685-7650

Vol. 1 No. 2 (2019), pp 58-63

DOI: https://doi.org/10.33366/jkn.v1i2.18

\title{
Persepsi Pendengar Tentang Citra RRI Pro 1 Stasiun Ende Flores Sebagai Radio Siaran Pedesaan
}

\author{
Maria Mega Mustika Jima ${ }^{1}$, Sugeng Rusmiwari ${ }^{2}$ \\ ${ }^{1,2}$ Program Studi Ilmu Komunikasi, Universitas Tribhuwana Tunggadewi \\ Email: mariamegajima@gmail.com
}

\begin{abstract}
The existence of Radio in the midst of the community has a very big role, because it is to meet the needs of the local community. Thus, the need for public perception about the image of RRI Ende Flores Pro 1. The purpose of this study is to find out how listeners' perceptions about the image of RRI Pro 1 and the supporting factors of the RRI Pro 1 image of Ende Flores station as a rural broadcast radio. In this study used a qualitative research method with data collection steps carried out through observation, documentation and interviews with informants in the field obtained through sampling. From that step, data analysis is performed using an interactive data analysis model that includes the process of data reduction, data presentation and drawing conclusions. From the research conducted, a conclusion has been reached; (1) Listeners' perceptions about the image of RRI Pro 1 Ende Flores Station as a rural radio broadcast viewed from motivation, attention, cognition, attitude and response. The perception has been built so that the community is greatly helped through rural broadcasts; (2) In building the listener's perception of the image of RRI pro 1 Ende Flores station, the supporting factors are stimulus, informative, time period in listening to rural broadcasts and perception. Which affects the formation of public perception through the program?
\end{abstract}

Keywords: Perception, Image, Radio

Abstrak : Keberadaan Radio di tengah-tengah masyarakat mempunyai peranan yang sangat besar, karena untuk memenuhi kebutuhan masyarakat setempat. Dengan demikian perlu adanya persepsi masyarakat tentang citra RRI Ende Flores Pro 1. Tujuan penelitian ini untuk mengetahui bagaimana persepsi pendengar tentang citra RRI Pro 1 dan faktor pendukung citra RRI Pro 1 stasiun Ende Flores sebagai radio siaran pedesaan. Dalam penelitian ini digunakan metode penelitian kualitatif dengan langkah-langkah pengumpulan data dilakukan melalui observasi, dokumentasi dan wawancara dengan informan dilapangan yang diperoleh melalui sampling. Dari langkah itu dilakukan analisa data dengan menggunakan model analisa data interaktif yang meliputi proses reduksi data, penyajian data dan penarikan kesimpulan. Dari penelitian yang telah dilaksanakan telah diperoleh suatu kesimpulan; (1) Persepsi pendengar tentang citra RRI Pro 1 Stasiun Ende Flores sebagai radio siaran pedesaan yang di lihat dari motivasi, perhatian, kognisi, sikap dan respons. Sudah terbangun persepsi sehingga masyarakat sangat terbantu melalui siaran pedesaan; (2) Dalam membangun persepsi pendengar tentang citra RRI pro 1 stasiun Ende Flores, adapun faktor pendukung yaitu stimulus, informatif, jangka waktu dalam mendengarkan siaran pedesaan dan persepsi. Yang mempengaruhi terbentuknya persepsi masyarakat melalui program tersebut.

Kata Kunci: Persepsi, Citra, Radio

\section{Pendahuluan}

Sampai sekarang, kendati peran media televisi menonjol ditengah masyarakat, tidak dapat dipungkiri bahwa keberadaan radio masih tetap relevan. Kedua media ini mampu memengaruhi masyarakat terutama yang jauh dari pusat pemerintahan dan pusat informasi (Althusser, 2002, dalam Juditha \& Darmawan, 2016). Fungsi tersebut dapat efektif sampai sejauh mana para pengelola siaran radio mampu mengemas informasi yang diudarakan.

Apabila pengelola radio mampu mengemas informasi yang diudarakan dengan baik dan benar, maka akan menimbulkan kesan baik pula pada masyarakat yang menerima 


\section{Jurnal Komunikasi Nusantara}

e-ISSN. 2685-7650

Vol. 1 No. 2 (2019), pp 58-63

DOI: https://doi.org/10.33366/jkn.v1i2.18

informasi tersebut. Informasi yang diterima masyarakat dari radio seharusnya dapat mewakili kebutuhan masyarakat akan informasi.

Radio merupakan media yang memiliki peranan penting dalam menyampaikan informasi, baik bersifat hiburan maupun pendidikan. Radio merupakah salah satu media massa tertua di dunia (Prasetyo \& Herlina, 2013) Mengingat radio adalah media komunikasi yang memiliki keunggulan dibandingkan dengan media cetak, yaitu hanya membutuhkan kemampuan mendengar bagi khalayak yang ingin mengaksesnya. Pendengar radio tidak terbatas pada ruang dan waktu, sedangkan pembaca surat kabar harus menyediakan waktu khusus untuk menelaah isinya (Olii, 2013: 05).

Radio Republik Indonesia (RRI) adalah lembaga penyiaran publik milik negara yang berjaringan terluas. Sampai dengan tahun 2011 memiliki 77 cabang se-Indonesia dan jaringan kurang lebih $80 \%$ wilayah. Sebagai Lembaga Penyiaran Publik. Memang penting bagi masyarakat untuk mengetahui langkah atau kebijakan pemerintah, namun bukan berarti yang disiarkan hanya berita baik, atauyang ikut terdidik bersikap kritis. padahal dibanyak kesempatan, para petinggi RRI sering mengatakan bahwa RRI berfungsi sebagai media penerangan, pendidikan, dan hiburan (Oramahi 2012: 06).

Citra adalah tujuan utama pada suatu perusahaan dan sekaligus merupakan reputasi dan prestasi yang hendak di capai bagi dunia dan hubungan masyarakat. Seperti penerimaan dan tanggapan baik positif maupun negatif yang khususnya dari publik dan masyarakat luas pada umumnya. Sebagaimana pendapat Qorib \& Syahida (2017) citra yang baik akan membuat sebuah lembaga atau perusahaan mencapai tujuannya dengan baik. Pembentukan citra ini sendiri menjadi tugas pokok dari public relations officer (Nurtjahjani \& Trivena, 2018:81)

Dalam penelitian ini penulis menggunakan jenis citra yang dikemukakan oleh Frank Jefkins dalam Syarifuddin dan Suryanto (2016: 157) yaitu citra perusahaan (Corporate Image). Alasan penulis memfokuskan pada citra itu karena sebagai radio milik negara penulis ingin mencari tahu apa saja strategi RRI Ende dalam menyampaikan informasi.

Program acara unggulan di RRI program satu adalah program siaran pedesaan. Informasi tentang persepsi masyarakat Kota Ende, sangatlah penting bagi RRI Ende. Dengan mengetahui persepsi masyarakat kota Ende, RRI dapat memformat acara yang sesuai dengan masyarakat. Melalui persepsi masyarakat Ende RRI dapat mengukur dan mengevaluasi progam acara siaran pedesaan berhasil atau tidak dalam melayani masyarakat. Melalui persepsi masyarakat RRI dapat mengetahui bahwa informasi sudah tepat sasaran maupun sebaliknya.

Dengan rumusan masalah dan tujuan penelitian Persepsi Pendengar Tentang Citra Rri Pro 1 Stasiun Ende Flores Sebagai Radio Siaran Pedesaan merupakan Salah satu harapan masyarakat dalam kaitan dengan siaran pedesaan adalah perubahan yang terbaik kepada masyarakat dalam rangka memberikan informasi. Bahkan menurut Rukmana dan Hariadi (2017) siaran RRI di pedesaan Solo Raya memiliki efektifitas sebesar 96 persen. 


\section{Jurnal Komunikasi Nusantara}

e-ISSN. 2685-7650

Vol. 1 No. 2 (2019), pp 58-63

DOI: https://doi.org/10.33366/jkn.v1i2.18

\section{Metode Penelitian}

Metode penelitian yang dilakukan merupakan kualitatif. Lokasi penelitian tempat di mana penelitian di lakukan, yang berhubungan sesuai dengan permasalahan yang di angkat oleh peneliti. Lokasi penelitian ini di RRI Stasiun Ende Flores, yang beralamat di Jalan Durian No 1 Kota Ende Flores. Sampel penelitian menggunakan purposive sampling. Sedangkan tenik pengumpulan data yang lakukan oleh peneliti adalah observasi, wawancara dan dokumentasi. Untuk metode analisa data yang digunakan yaitu metode deskriptif, di mana mendeskripsikan hasil data yang diperoleh.

\section{Hasil Penelitian dan Pembahasan \\ Persepsi Pendengar Tentang Citra RRI Pro 1 Stasiun Ende Flores sebagai Radio Siaran Pedesaan}

1. Motivasi

Motivasi adalah dorongan, hasrat, atau penggerak yang berasal dari dalam diri pendengar untuk melakukan tindakan tertentu. Alwisol (2018:356) mengungkapkan pemikiran Dollard \& Miller, bahwa manusia banyak memiliki dorongan yang dipelajari dari kehidupan nyata, seperti dorongan untuk makan ketika lapar.

Motivasi akan mempengaruhi perhatian pendengar terhadap program siaran pedesaan dan pada gilirannya akan mempengaruhi persepsi mereka. Kegiatan atau aktivitas yang diminati merupakan faktor yang cukup penting sebagai suatu deskripsi tentang kecenderungan minat atau motivasi pendengar dalam mengisi waktu mereka di luar pekerjaan pokok.

Hal ini terkait sebagai faktor lingkungan pendengar yang bisa berpengaruh terhadap perhatian serta motivasi selektif serta sebagai kerangka rujukan yang mempengaruhi penilaian atau persepsi pada program siaran pedesaan RRI Ende. Sebagian besar nara sumber dalam penelitian memiliki motivasi mendengarkan program siaran berita dan informasi di RRI untuk memperoleh tambahan wawasan.

Dapat disimpulkan bahwa informasi yang disampaikan RRI Pro 1 mengenai siaran Pedesaan sangatlah bermanfaat bagi masyarakat kelurahan Rewarangga dalam rangka membangun wilayahnya.

2. Perhatian

Perhatian merupakan salah satu faktor yang mempengaruhi citra. Perhatian terjadi dikarenakan audiens atau khalayak bersifat selektif terhadap stimulus yang ada di sekitarnya. Mereka bersifat selektif terhadap stimulus yang menonjol dalam kesadarannya akan mendapat perhatian, dan yang lainnya akan terabaikan. Baik atau buruknya persepsi masyarakat rewarangga terhadap program siaran pedesaan sangat dipengaruhi seberapa besar perhatian masyarakat. Perhatian merupakan faktor-faktor selektif yang membentuk persepsi masyarakat, di samping faktor lainnya.

Dapat disimpulkan bahwa siaran pedesaan tersebut dapat membentuk persepsi dimasyarakat guna membangun pemahaman dalam rangka kemajuan daerah Rewarangga. 


\section{Jurnal Komunikasi Nusantara}

e-ISSN. 2685-7650

Vol. 1 No. 2 (2019), pp 58-63

DOI: https://doi.org/10.33366/jkn.v1i2.18

\section{Kognisi}

Kognisi merupakan aspek pengetahuan yang berhubungan dengan kepercayaan ide dan konsep. Pentingnya siaran pedesaan bagi masyarakat sebagai ilmu dan pengetahuan yang dapat diperoleh dalam penambahan pemahaman baru. Siaran pedesaan merupakan program RRI Pro 1 Stasiun Ende, sebagai media informasi dan edukasi bagi masyarakat.

Dapat disimpulkan bahwa siaran pedesaan banyak memberi pengetahuan seputar ilmu pertanian bagi masyarakat dalam menjalankan aktivitas pertaniannya.

4. Sikap

Sikap merupakan hasil evaluasi negatif atau positif terhadap konsekuensi konsekuensi penggunaan suatu objek. Sikap ini suatu keyakinan yang diterjemahkan dalam tindakan Schwartz (dalam Palupi \& Sawitri, 2017). Program siaran pedesaan RRI Pro 1 Stasiun Ende, dapat memberi pengaruh pada pandangan masyarakat dalam beraktifitas dengan melihat program tersebut sebagai pijakan pilihan dalam berperilaku dengan harapan yang lebih bermanfaat.

Dapat disimpulkan bahwa siaran pedesaan banyak memberikan pengetahuan yang berguna bagi masyarakat untuk membentuk sikap positif guna menghadapi tantangan global dan mampu berdaya saing melalui produksi pertanian masyarakat.

5. Respons

Respons merupakan perilaku berupa aktivitas seseorang yang berupa tindakan sebagai aksi terhadap rangsangan atau stimulus. Melaui siaran pedesaan RRI Pro 1 Stasiun Ende, dapat memberi kesan kepada setiap pihak yang mendengarkan ataupun para pengambil kebijakan dapat menjadikannya sebagai rujukan yang bermutu bagi pembangunan. Harapan akan respons dapat memberi kesan bagi setiap orang.

Bahwa siaran pedesaan banyak memberikan kesan bagi masyarakat. Sehingga masyarakat dapat merubah pola pikir dan tindakan kearah yang lebih maju. Hal ini juga dapat memberi dampak pada pemerintah atau pengambil kebijakan setelah mendapat informasi langsung terkait kondisi masyarakat, melalui program siaran pedesaan.

\section{Faktor Pendukung Citra RRI Pro 1 Stasiun Ende Flores sebagai Radio Siaran Pedesaan.}

Adapun faktor pendukung dalam rangka proses pembentukan citra RRI Pro 1 Stasiun Ende yaitu :

1. Stimulus

Stimulus merupakan rangasangan yang mengaktifkan bagian-bagian tubuh. Untuk organisasi, stimulus pembentuk citra berkaitan dengan informasi yang berasal dari luar yang menggambarkan sebuah proses pembentukan citra.

Siaran pedesaan RRI Pro 1 Stasiun Ende, merupakan program informatif bagi masyarakat diwilayah pedesaan terkait informasi tentang pengetahuan yang berhubungan dengan pertanian dan kondisi sosial masyarakat desa. Hal ini sangat dibutuhkan sebagai suatu informasi dan edukasi bagi masyarakat masyarakat. Melihat pentingnya program tersebut 


\section{Jurnal Komunikasi Nusantara}

e-ISSN. 2685-7650

Vol. 1 No. 2 (2019), pp 58-63

DOI: https://doi.org/10.33366/jkn.v1i2.18

yang dapat bermanfaat bagi masyarakat. Untuk itu lembaga penyiaran sangat dibutuhkan dalam membangun persepsi di masyarakat.

Dapat disimpulkan bahwa siaran pedesaan RRI Pro 1 Stasiun Ende sangat dibutuhkan dan digemari masyarakat sebgai media informasi bagi masyarakat dan membangun persepsi. Untuk itu peran lembaga penyiaran menjadi pilar penting pemberi informasi yang edukatif bagi masyarakat. Mengingat masyarakat masih menggemari dan membutuhkan peran radio.

2. Informatif

Program acara Siaran Pedesaan menjadi sarana informasi bagi para petani dan penyuluh pertanian untuk diaplikasikan langsung di lapangan. Khususnya bagi penyuluh pertanian, program acara siaran pedesaan menjadi sarana belajar yang memperkaya pengetahuan mengenai teknologi pertanian yang tentunya dapat disampaikan kembali ketika mereka melakukan penyuluhan pada para petani dan masyarakat luas.

Dapat disimpulkan bahwa siaran pedesaan RRI Pro 1 Stasiun Ende sangat dibutuhkan masyarakat sebagai media informasi dan edukasi. Hal ini sangat membantu masyarakat dalam menjalankan aktivitas pertanian guna meningkatkan produktifitas pertanian masyarakat rewarangga serta membantu penyuluh pertanian.

3. Jangka waktu dalam mendengarkan Siaran Pedesaan

Jangka waktu masyarakat dalam mendengarkan program siaran pedesaan adalah jangka waktu yang dimiliki oleh pendengar dalam mendengarkan program siaran tersebut, terutama terkait dengan sudah atau belum lamanya masyarakat mendengarkan siaran pedesaan di RRI Pro 1 Stasiun Ende.

Faktor ini sangat berpengaruh terhadap kualitas kemampuan selektifitas masyarakat terhadap suatu yang menjadi perhatiannya, yaitu untuk mengetahui latar belakang ketertarikan masyarakat dalam mendengarkan program siaran pedesaan RRI Pro 1 Stasiun Ende.

Bahwa siaran pedesaan RRI Pro 1 Stasiun Ende, Sangat rutin didengarkan oleh masyarakat rewarangga sebab Radio masih merupakan sarana informasi bagi masyarakat dalam meningkatkan kualitas pertanian yang berpengaruh pada peningkatan perekonomian masyarakat. Itensitas mendengar sangat berpengaruh pada pembentukan persepsi masyarakat terkait dengan pola pikir dan pola tindakan masyarakat tani rewarangga.

\section{Persepsi}

Persepsi merupakan hasil pengamatan terhadap unsur lingkungan dikaitkan dengan suatu pemahaman. Persepsi juga merupakan salah satu aspek psikologis yang penting bagi manusia dalam merespon kehadiran berbagai aspek dan gejala disekitarnya. Siaran Pedesaan RRI Pro 1 Stasiun Ende sangat membantu dalam pembentukan persepsi bagi masyarakat terkait dengan pemahaman dan kondisi masyarakat pada masalah pertanian.

Bahwa siaran pedesaan RRI Pro 1 Stasiun Ende, sangat membantu pembentukan persepsi bagi masyarakat Petani Rewarangga, karena memberikan informasi dan edukasi terkait pengetahuan pertanian dan gambaran kondisi masalah pertanian. Sejauh ini program siaran pedesaan sudah banyak membantu para petani melalui lembaga penyiaran publik yang berpihak pada kepentingan masyarakat. 


\section{Jurnal Komunikasi Nusantara}

e-ISSN. 2685-7650

Vol. 1 No. 2 (2019), pp 58-63

DOI: https://doi.org/10.33366/jkn.v1i2.18

\section{Kesimpulan}

Berdasarkan hasil penelitian, maka peneliti dapat menyimpulkan bahwa persepsi pendengar tentang citra rri pro 1 stasiun ende flores sebagai radio siaran pedesaan serta faktor pendukung citra sebagai berikut:

1. Persepsi pendengar tentang citra RRI Pro 1 Stasiun Ende Flores sebagai radio siaran pedesaan yang di lihat dari motivasi, perhatian, kognisi, sikap dan respons. Sudah terbangun persepsi sehingga masyarakat sangat terbantu melalui siaran pedesaan.

2. Dalam membangun persepsi pendengar tentang citra RRI pro 1 stasiun ende flores, adapun faktor pendukung yaitu stimulus, informatif, jangka waktu dalam mendengarkan siaran pedesaan dan persepsi. Yang mempengaruhi terbentuknya persepsi masyarakat melalui program tersebut.

\section{Daftar Pustaka}

Alwisol. (2018). Psikologi Kepribadian. Malang: UMM Press

Juditha, C. \& Darmawan, J. (2016). Terpaan Siaran RRI dan TVRI pada Masyarakat di Wilayah Perbatasan RI-Timor Leste. Jurnal Komunikasi, Media, dan Informatika. Vol 5 No 1 Pg 19-28

Nurtjahjani, F. \& Trivena, S. M. (2018). Public Relations, Citra dan Praktek. Malang: UPT Percetakan dan Penerbitan Polinema.

Olii, H. (2013). Reportase Radio Dan Televisi Bahan Ajar Di Perguruan Tinggi. Edisi 2. Jakarta: PT. Indeks.

Oramahi, H. A. (2012). Jurnalistik Radio: Kiat Menulis Berita Radio. Jakarta: Erlangga.

Palupi, T. \& Sawitri, D. R. (2017). Hubungan Antara Sikap Dengan Perilaku Pro-Lingkungan Ditinjau dari Perspektif Theory Of Planned Behavior. Proceeding Biology Education Conference. Hal 214-217

Prasetyo, R. \& Herlina, M. (2013). Hubungan Antara Radio Streaming dengan Persepsi dan Kepuasan Audiens di PT MNC Skyvision Jakarta. Jurnal Komunikasi Aspikom. Vol. 2 No. 1 Pg 589-602

Qorib, F. \& Syahida, A. R. (2017). Strategi Museum Angkut Kota Batu dalam Membangun Hubungan dengan Media Massa. Jurnal Reformasi: Vol. 7 No. 1 Pg 47-55.

Rukmana, L. G. \& Hariadi, S. S. (2017). Keefektifan Program Siaran Pedesaan RRI Surakarta dalam Pemenuhan Kebutuhan Informasi Pertanian Anggota Pandheman Siaran Pedesaan di Solo Raya. Repository Universitas Gajahmada. http://etd.repository.ugm.ac.id/home/detail_pencarian/115556

Syarifuddin \& Suryanto. (2016). Public Relations. Yogyakarta: C.V Andi Offset. 